\title{
Peran Pasuruan Industrial Estate Rembang (PIER) terhadap kehidupan masyarakat (sosial-ekonomi) Desa Mojoparon Kecamatan Rembang Kabupaten Pasuruan
}

\author{
Yonita Yuli Amanda, Sukamto*, Siti Malikhah Towaf \\ Universitas Negeri Malang, Jl. Semarang No. 5 Malang, Jawa Timur, Indonesia \\ *Penulis korespondensi, Surel: sukamto.fis@um.ac.id
}

Paper received: 02-03-2021; revised: 15-03-2021; accepted: 30-03-2021

\begin{abstract}
This research aims to describe the role of Pasuruan Industrial Estate Rembang (PIER) to the socioeconomic life of Mojoparon villagers in Pasuruan Regency. The approach and type of research used qualitatively descriptive. Three research conclusions were obtained as follows. First, the history of its establishment in PIER is due to the development of SIER and the development of industry in Pasuruan District phase III. Second, the problem of pier role for Mojoparon village community is divided into two, namely, indirect role and direct role. The indirect role is economic growth and increased employment opportunities. Direct role in the form of village infrastructure assistance, APAP cooperation, and PK and BK programs. Third, the impact of PIER for Mojoparon villagers is more prosperous and utilized pier industrial waste. At the same time the benefits of this research for IPS education can be used as additional insights and can foster socially sensitive, positive and skilled attitudes.
\end{abstract}

Keywords: industry; PIER; Mojoparon Village community

\begin{abstract}
Abstrak
Penelitian ini bertujuan untuk mendeskripsikan peranan keberadaan Pasuruan Industrial Estate Rembang (PIER) pada kehidupan sosial ekonomi masyarakat Desa Mojoparon Kecamatan Rembang Kabupaten Pasuruan. Pendekatan dan jenis penelitian yang digunakan kualitatif deskriptif. Berdasarkan kesimpulan penelitian ini ada tiga garis besar yakni. Pertama, sejarah berdirinya di PIER merupakan pengembangan dari SIER selain itu adanya pengembangan industri di Kabupaten Pasuruan tahap III. Kedua, masalah peranan PIER bagi masyarakat Desa Mojoparon dibagi menjadi dua yaitu, peranan secara tidak langsung dan peranan secara langsung. Peranan tidak langsung yaitu pertumbuhan ekonomi dan kesempatan kerja meningkat. Peranan langsung berupa bantuan infrastruktur desa, kerjasama APAP, dan Program PK dan BK. Ketiga, dampak PIER bagi masyarakat Desa Mojoparon yaitu semakin sejahtera dan dimanfaatkannya limbah industri PIER. Sekaligus manfaat penelitian ini bagi pendidikan IPS dapat dijadikan tambahan wawasan dan dapat menumbuhkan sikap peka sosial, positif dan terampil.
\end{abstract}

Kata kunci: industri; PIER; masyarakat Desa Mojoparon

\section{Pendahuluan}

Industri adalah suatu upaya memproses barang kemudian pengolahannya menggunakan tenaga manusia dibantu oleh tenaga mesin. Industri memanfaatkan sumber daya alam yang ada dari barang yang tidak memiliki nilai guna, menjadi barang dengan nilai guna yang lebih tinggi. Tujuan industri adalah untuk menghasilkan keuntungan yang maksimal. Menurut (Siswanta, 2011) kelompok usaha yang menjual barang maupun jasa serta memproduksinya disebut juga dengan industri. Industri juga bisa diartikan sebagai kegiatan ekonomi dalam mengolah bahan mentah, bahan baku, barang setengah jadi dan barang jadi dengan nilai yang lebih tinggi. 
Perkembangan industri di Indonesia dimulai dengan membangun wilayah industri pertama yakni Jakarta Industrial Estate Pulo Gadung (JIEP) dan kemudian pada tahun 1974 disusul oleh Surabaya Industrial Estate Rungkut (SIER). Kawasan SIER ada tiga yang dikelola yaitu SIER, Sidoarjo Industrial Estate Berbek (SIEB), dan Pasuruan industrial Estate Rembang (PIER). Kemudian disusul kawasan industri (KI) lainnya yang dikembangkan oleh pemerintah, antara lain KI Cilacap (1974), KI Medan (1975), KI Makasar (1978), KI Cirebon (1984) dan KI Lampung (1986) (Kwanda, 2000).

PIER merupakan kawasan industri yang mempunyai luas $563 \mathrm{Ha}$, dan saat ini telah terisi seluas 260 ha dengan 87/164 perusahaan/lokasi dengan 45 Penanaman Modal Asing (PMA) dan 42 Penanaman Modal Dalam Negeri (PMDN) yang menampung 23.199 tenaga kerja (Anonim, 2014). Alasan penelitian dilaksanakan di kawasan industri PIER, atas pertimbangan ketertarikan peneliti untuk mengetahui peranan keberadaan kawasan industri terhadap kehidupan masyarakat di sekitar kawasan industri. Berdirinya PIER dapat menimbulkan efek negatif yaitu adanya limbah pengolahan industri terhadap lingkungan, khususnya masyarakat Desa Mojoparon yang bertempat tinggal di belakang kawasan PIER.

Alasan pemilihan lokasi di desa Mojoparon dikarenakan keberadaan desa yang sangat dekat dengan kawasan industri PER dan telah banyak menyerap tenaga kerja di desa tersebut. Perubahan mata pencaharian yang terjadi berpengaruh terhadap pola pikir dan perilaku masyarakat, hal itu terbukti dari adanya pergeseran sektor agraris menjadi sektor industri dan berdampak pada kehidupan sosial ekonomi masyarakat. Perubahan sosial menurut Soekanto (2012) merupakan perubahan yang terjadi dalam masyarakat, dan memengaruhi sistem sosialnya. Sistem sosial tersebut termasuk nilai-nilai, sikap dan pola perilaku individu atau kelompok masyarakat.

\section{Metode}

Pendekatan dan jenis penelitian ini menggunakan pendekatan dan jenis penelitan kualitatif deskriptif. Peran kehadiran peneliti sebagai pengumpul data. Penelitian ini dilaksanakan di Desa Mojoparon. Dalam penelitian ini menggunakan sumber data primer dan data sekunder, dengan informan kunci dan informan pendukung yang dipilih secara purposif. Pengumpulan data dalam penelitian ini melalui prosedur diantaranya observasi, wawancara, dan dokumentasi. Model analisis data yang digunakan yakni model analisis interaktif Miles dan Huberman. Supaya keabsahan temuan valid maka digunakan triangulasi (metode, sumber dan waktu), dan kecukupan referensial. Tahapan penelitian yaitu tahap persiapan, tahap rancangan, tahap pelaksanaan, dan tahap pelaporan.

\section{Hasil dan Pembahasan}

\subsection{Sejarah Pasuruan Industrial Estate Rembang (PIER)}

Berdasarkan hasil penelitian yang dilakukan berdirinya kawasan industri PIER dikarenakan adanya pengembangan kawasan industri di Surabaya yang bernama SIER. Surabaya Industrial Estate Rungkut (SIER) berada pada area seluas 245 Ha dengan tenaga kerja sebanyak puluhan ribu pekerja. SIER memiliki tiga kawasan industri yang dikelola yaitu Sidoarjo Industrial Estate Berbek (SIEB), SIER, dan PIER. Berdirinya kawsan industri PIER juga dikarenakan adanya program pengembangan kawasan industri di Kabupaten Pasuruan yaitu program pengembangan industri tahap III. Kawasan industri menurut (Kartasapoetra, G. Kartasapoetra, A.G. Kartasapoetra, R.G., 1987) suatu areal tanah yang telah dimatangkan dan 
dibagi atas kapling-kapling sesuai dengan rencana yang disusun secara menyeluruh dengan kemudahan sarana jalan, transportasi, pengolahan limba dan fasilitas lainnya.

Proses berdirinya kawasan industri PIER dimulai dari pembebasan tanah tahun 1989. Kemudian pemerataan tanah pada tahun 1996 dan tahun 1997 mulai masuknya perusahaanperusahaan baru ke dalam kawasa industri PIER. Faktor-faktor berdirinya kawasan industri di PIER dikarenakan kesesuaian dengan zona merah industri yang terdapat di Pasuruan, ketersediaan air industri, jangkauan instalasi listrik dan kemudahaan pembuangan limbah. Selain itu kondisi daerah Kecamatan Rembang yang kering, menjadikan daerah Rembang sangat cocok sebagai wilayah industri. Kondisi yang demikian juga dapat mempermudah perusahaan atau pabrik dalam memproduksi barang dan proses pendistribusiannya.

Berdirinya kawasan industri PIER tidak terlepas dari adanya pro dan kontra. Pro dan kontra terjadi karena adanya kekhawatiran masyarakat desa akan dampak industri bagi masyarakat sekitar dan nasib ekonominya nanti. Akan tetapi seiring dengan berkembangnya waktu masyarakat menyadari hal tersebut. Dikarenakan berdirinya kawasan industri PIER akan memberikan dampak yang positif bagi warga. Meskipun tidak terjadi demo yang dilakukan oleh masyarakat Desa Mojoparon, akan tetapi terjadi perdebatan awal dikarenakan batas-batas tanah atau perekrutan karyawan yang harus mengambil dari masyarakat sekitar.

PIER yang memiliki kurang lebih 80 perusahaan dengan jumlah tenaga kerja 23.000 pekerja merupakan industri yang besar. Menurut (Badan Pusat Statistik, 2015) industri besar adalah usaha industri pengolahan yang mempunyai pekerja atau karyawan 100 orang atau lebih. Kelompok industri yang terdapat di PIER antara lain: kelompok industri makanan atau pengalengan ikan, industri smelting, industri furniture, industri perakitan traktor mesin, dan industri rokok. Jenis industri yang paling banyak adalah jenis atau kelompok industri furniture.

\subsection{Kehidupan Masyarakat Desa Mojoparon (Sosial Ekonomi) sebelum adanya PIER}

Berdirinya kawasan industri PIER tidak terlepas dari situasi atau kondisi masyarakat desa di sekitar kawasan industri. Salah satu desa tersebut yaitu Desa Mojoparon. Kondisi masyarakat Desa Mojoparon sebelum adanya kawasan industri PIER menggantungkan hidupnya kepada sektor agraris yaitu sebagai masyarakat petani. Masyarakat Petani menurut Salim dan Kahono (_:54) mayoritas masyarakat di daerah desa yang menekuni pertanian dan mengelola sumber daya alam untuk keperluan hidup masih masuk dalam kategori sederahana. Beberapa pekerjaan pekerjaan sampingan yang dilakukan, seperti pedagang, tukang kayu, dan pengrajin.

Hasil kegiatan pertanian dan perkebunan masyarakat Desa Mojoparon sebelum adanya PIER merupakan tanaman padi dan biji buah mente. Pada saat itu tanaman atau lahan perkebunan biji buah mente sangat banyak. Akan tetapi dikarenakan pembangunan kawasan industri menjadi berkurang. Kehidupan sosial ekonomi masyarakat Desa Mojoparon sebelum adanya PIER cenderung sulit, dikarenakan dahulu para petani cenderung menghabiskan biaya banyak untuk kegiatan produksi dan harga jual hasil pertanian serta perkebunan yang sangat rendah. Hal tersebut membuat masyarakat Desa Mojoparon yang bekerja menjadi petani menjual tanahnya. 


\subsection{Peranan Pasuruan Industrial Estate Rembang (PIER) dalam Kehidupan Masyarakat Desa Mojoparon (Sosial dan Ekonomi) Kecamatan Rembang Kabupaten Pasuruan.}

Berdasarkan hasil penelitian yang didapat, peranan PIER dibagi menjadi peran tidak langsung dan peranan langsung.

\subsubsection{Peranan Pasuruan Industrial Estate Rembang (PIER) secara Tidak Langsung.}

Berdasarkan hasil penelitian yang didapat peranan tidak langsung dari berdirinya kawasan PIER yang pertama ialah memberikan kontribusi berupa pertumbuhkan ekonomi masyarakat sekitar kawasan industri PIER. Dilihat dari peningkatan pendapatan masyarakat sebelum menjadi karyawan industri yang rendah, berkisar antara Rp 250.000,00 dan setelah menjadi karyawasan industri menjadi Rp 3.100.000,00. Menurut (Ernita, Dewi. Amar, Syamsul \& Sofyan, Efrizal, 2013) pertumbuhan ekonomi salah satu masalah dalam lingkar perekonomian masyarakat dalam jangka panjang untuk menuju keadaan yang lebih baik selama periode tertentu. Dapat dikaitkan sebagai keadaan meningkatnya kapasitas produksi suatu perekonomian yang diwujudkan dalam bentuk peningkatan pembangunan nasional.

Peranan tidak langsung kedua yang ialah munculnya berbagai kesempatan kerja, baik sebagai karyawan di perusahan PIER maupun memberikan berbagai peluang pekerjaan di masyarakat seperti kos kosan, toko pracang, tukang ojek, rental mobil antar jemput karyawan. Kesempatan kerja sebagai karyawan industri yang diberikan PIER bagi masyarakat Desa Mojoparon, dengan diberikan kepada Kepala Desa Mojoparon apabila ada perusahaan baru di kawasan PIER. (Djunaedi, M. Hendra, 2009) kesempatan kerja merupakan peluang yang diwujudkan dengan tersedianya lapangan kerja yang memungkinkan untuk bekerja tesebut.

\subsubsection{Peranan Langsung Pasuruan Industrial Estate Rembang (PIER).}

Berdasarkan hasil penelitian yang didapat peranan langsung PIER bagi masyarakat Desa Mojoparon dibagi menjadi bantuan dan program atau kebijakan. Bantuan tersebut berupa bantuan infastruktur dan faslitias, seperti infrasktur jalan, penerangan, gorong-gorong, rehab musholla, pos kamling dan sebagainya. Bantuan fasilitas berupa mobil antar jemput karyawan dengan melakukan kerjasama yang dilakukan dengan masyarakat, pihak PIER dan Dirgen Perhubungan dan Angkutan Jalan yang dinamakan Asosiasi Paguyupan Angkutan PIER (APAP). Kerjasama menurut Soepono, dkk (1995:62) terjadi jika permintaan akan barang dari satu pihak kepada pihak lain dan menimbulkan hubungan pekerjaan dari kedua belah pihak tersebut.

SIER merupakan perusahaan di bawah kementrian Badan Usaha Milik Negara (BUMN). Jadi program-program PIER harus mengikuti ketentuan menteri keuangan. Program atau kebijakan yang diberikan PIER ada dua yaitu program Bina Lingkungan (BK) dan Program Kemitraan (PK). Program Bina Lingkungan merupakan program bantuan untuk masyarakat seperti fasilitas dan program sosial lainnya, seperti: pemberian bantuan hibah untuk kegiatan pengajian, rehap masjid, mushollah, pembuatan pos kamling, perbaikan Taman Pendidikan AlQuran (TPQ) atau madrasah, dan program sosial non pemerintah lainnya. Sedangkan Program Kemitraan dilakukan untuk pemberian modal usaha atau pinjaman untuk masyarakat sekitar dalam pembuatan usaha, seperti: pemberian pinjaman bergulir untuk modal usaha pengrajin 
keset, bordil kain, toko pracang, kos kosan, dan pengrajin mebel. Program ini diberikan dalam jangka waktu sekitar 2 tahun.

\subsection{Kehidupan Masyarakat desa Mojoparon Kecamatan Rembang Kabupaten Pasuruan sebagai dampak dari Pasuruan Industrial Estate Rembang (PIER).}

PIER merupakan kawasan industri yang memberikan berbagai dampak bagi kehidupan masyarakat, khususnya masyarakat setempat. Keberadaan PIER di sekitar area penduduk dapat memberikan dampak yang bersifat fisik maupun nonfisik. Dampak nonfisik dan fisik dengan adanya industri dapat berupa dampak sosial ekonomi. Selain itu dampak lain yang ditimbulkan dengan adanya industri yaitu dampak lingkungan.

\subsubsection{Kehidupan Sosial Ekonomi Masyarakat desa Mojoparon Kecamatan Rembang Kabupaten Pasuruan Dampak dari Pasuruan Industrial Estate Rembang (PIER).}

Berdasarkan hasil penelitian yang didapat kondisi sosial ekonomi masyarakat Desa Mojoparon setelah berdirinya kawasan PIER mengalami perubahan kegiatan ekonomi, yaitu dari sektor pertanian menjadi sektor industri. Menurut Darojah (2012:80) perubahan sistem ekonomi merupakan perubahan pekerjaan utama masyarakat yang berubah setelah adanya pembangunan ekonomi yang ada, misalnya dari ekonomi pertanian dengan pekerjaan utama sebagai petani, berubah ke ekonomi industri sebagai karyawan industri. Berubahnya pekerjaan masyarakat juga akan mempengaruhi pendapatan masyarakat desa. Saat ini pendapatan masyarakat yang bekerja sebagai karyawan industri mencapai Rp 6000.000,00 hingga Rp 7.0000.000,00 setiap bulan.

Meningkatnya pendapatan rata-rata masyarakat Desa Mojoparon maka akan menimbulkan peningkatan kesejahteraan masyarakat. Kesejahteraan sosial menurut Fahrudin (2012:40) merupakan gambaran tentang masyarakat dimana tata kehidupan sosial materiil maupun spiritual diselimuti keselamatan, kesusilaan, dan ketentraman lahir dan batin. Alasan pekerja memilih bekerja di perusahaan untuk meningkatkan perekonomian dan kesejahteraan keluarganya. Pilihan menjadi seorang pekerja industri dipengaruhi oleh tujuan dan adanya pengaruh dari kawasan PIER. Menurut Ritzer (2007:395) tindakan perseorangan yang mengarah kepada suatu tujuan dan ditentukan oleh nilai atau pilihan disebut dengan teori pilihan rasional. Jadi masyarakat Desa Mojoparon yang bekerja sebagai pekerja industri didasari oleh tujuan yang bersifat bermanfaat dan mensejahterahkan.

Kehidupan sosial ekonomi masyarakat Desa Mojoparon setelah adanya PIER cenderung kurang bermasyarakat atau bisa disebut individualis. Individualis menurut Kamus Besar Bahasa Indonesia (2008) paham yang menghendaki kebebasan dalam berbuat dan menganut suatu kepercayaan bagi setiap orang. Sifat individualis masyarakat Desa Mojoparon dikarenakan pekerjaan menjadi karyawan industri yang dimulai dari pagi hari hingga malam hari ataupun sebaliknya.

Dampak sosial yang kedua adalah munculnya sifat materialistis. Sifat materialistis tersebut nampak dari tidak adanya organisasi sosial masyarakat di Desa Mojoparon dan sebagian anggota masyarakat yang bekerja di PIER memilih ikut dalam organisasi sosial yang dibuat oleh PIER. Organisasi sosial tersebut bernama Serikat Pekerja Satuan Indonesia (SPSI). Tujuan organisasi sosial SPSI untuk menyuarakan aspirasi dan hak-hak buruh pekerja PIER. 
Aspirasi tersebut berupa hak-hak tentang peningkatan gaji dan masalah dalam perusahaan. Materalistis menurut Salim (2010:183) memandang materi sebagai keseluruhan manusia dan menganggap manusia hanyalah sesuatu yang ada, dan tanpa menjadi subjek.

Dampak ketiga yang timbul adalah adannya kecemburuan sosial yang terjadi di tengah masyarakat. Kecemburuan sosial yang terjadi di Desa Mojoparon dikarenakan masalah perekrutan tenaga kerja. Perusahaan di PIER juga mempunyai grade atau syarat masuk menjadi pekerja di PIER, tidak jarang masyarakat Desa Mojoparon tidak dapat bersaing dengan sesama masyarakat Desa Mojoparon atau daerah lain. Menurut Widiyanarti (2005:81) kecemburuan sosial pada masyarakat industri dapat dapat terjadi jika suatu kesalahan pengelolaan dari komunitas perusahaan terhadap lingkungannya yang mengakibatkan kerugian. Jadi perusahaan harus mempunyai kewajiban sosial terhadap masyarakat atau berdiri sejajar dan saling membutuhkan, seperti perekrutan kerja bagi masyarakat lokal.

\subsubsection{Kehidupan Masyarakat desa Mojoparon Kecamatan Rembang Kabupaten Pasuruan dan Dampak Limbah Pasuruan Industrial Estate Rembang (PIER).}

Limbah industri PIER berupa limbah padat non B3, limbah cair, dan limbah B3. Secara umum pengelolaan limbah di PIER menggunakan sistem biologis. Setiap perusahaan di PIER mempunyai tempat pengelolaan masing-masing, akan tetapi untuk limbah cair disalurkan ke Intalasi Pengolahan Air Limbah (IPAL) PIER setelah memenuhi baku mutu proses IPAL PIER.

Jenis Limbah padat non B3 di PIER merupakan limbah padat yang dapat diolah kembali atau limbah yang tidak beracun. Di Desa Mojoparon limbah non B3 dikerjasamakan dengan masyarakat sekitar yang memenuhi standart perijinan dalam pengelolahan limbah padat non B3. Sedangkan limbah B3 merupakan limbah yang beracun dan sesuai Undang-Undang limbah beracun harus dibuang ke tempat yang sudah ditentukan oleh undang-undang. PIER yang sudah terintegrasi dalam pengelompokan industri-industri besar dalam satu kawasan yang dan telah memilki berbagai fasilitas, baik fasilitas untuk karyawan maupun faslitias pengelolaan limbah.

Menurut Kartasapoetra (1985:92) pengaruh industri yaitu berubahnya nilai-nilai yang memberi input kepada masyarakat. Sehingga membentuk sikap dan tingkah laku dalam bekerja dan sekaligus merubah lingkungan fisik yang meliputi perkembangan kota, pertambahan penduduk, timbulnya polusi dan biaya hidup yang meningkat. Di Desa Mojoparon dampak limbah PIER pernah terjadi pada awal pendirian PIER. Limbah tersebut berasal dari perusahaan atau pabrik tulang, pabrik tersebut akhirnya didemo dan hasilnya pabrik tersebut ditutup. Selain itu limbah PIER juga dimanfaatkan oleh masyarakat desa Mojoparon menjadi kerajinan keset yang dibuat dari limbah padat non B3 dengan harga jual berkisar Rp. 5.000,00 hingga Rp. 10.000,00.

\subsubsection{Manfaat Peranan Pasuruan Industrial Estate Rembang (PIER) Terhadap Kehidupan Sosial Ekonomi Masyarakat Desa Mojoparon dan pengaruhnya bagi Pendidikan IPS}

Keberadaan PIER memberikan peranan yang sangat besar bagi Desa Mojoparon. Selain itu juga menimbulkan sebuah perubahan sosial yang dapat bermanfaat sebagai kajian dalam Pendidikan Ilmu Pengetahuan Sosial. Keberadaan PIER merupakan fenomena sosial dan kenyataan sosial yang berpengaruh terhadap kehidupan masyarakat di sekitarnya. 
Kajian penelitian ini sesuai dengan kurikulum 2013 di SMP dengan kompetensi dasar 3.4 dengan tema "Dinamika Interaksi Manusia dengan Lingkungan Alam, Sosial, Budaya dan Ekonomi". Selain itu penelitian ini juga dapat dikaitkan dengan hubungan antara ruang dan waktu dari kehidupan masyarakat desa sebelum adanya industri dengan setelah adanya industri. Hal tersebut dapat dikaitkan dengan kompetensi dasar 3.1 yaitu "Memahami aspek keruangan dan konektivitas antar ruang dan waktu dalam lingkup regional serta perubahan dan keberlanjutan kehidupan manusia (ekonomi, sosial, budaya, pendidikan, dan politik)" (Permendikbud, 2013: 55-56).

Tujuan Pendidikan Ilmu Pengetahuan Sosial yaitu agar dapat mengembangkan sikap peserta didik yang peka terhadap fenomena atau masalah sosial yang terjadi di lingkungannya, memilki mental positif atas perbaikan pada ketimpangan sosial, terampil dalam memecahkan masalah (Trianto, 2007:128). Peserta didik yang mampu memahami berdirinya industri bagi masyarakat desa maka akan menimbulkan sikap peka sosial terhadap fenomena sosial yang ada dan diharapkan peserta didik dapat menumbuhkan sikap terampil dalam pemecahan masalah. Jika materi tersebut telah mampu dipahami oleh peserta didik diharapkan mempunyai sikap yang peka terhadap masalah sosial dan lingkungan sekitarnya.

\section{Simpulan}

Sejarah PIER dimulai dari adanya pengembangan kawasan Surabaya Industrial Estate Rungkut (SIER). Selain itu dikarenakan adanya pengembangan kawasan industri di Kabupaten Pasuruan yaitu program pengembangan industri tahap III. Di Desa Mojoparon tidak dilakukan demo yang berkepanjangan dikarenakan sudah adanya perjanjian yang telah dibuat yang menghasilkan batas-batas tanah dan perekrutan karyawan. Kehidupan sosial ekonomi masyarakat Desa Mojoparon saat itu juga cenderung lebih sulit dikarenakan untung sebagai petani yang rendah. Peranan PIER bagi kehidupan sosial ekonomi dibagi menjadi dua yaitu (1) Peranan tidak langsung yaitu tumbuhnya pertumbuhan ekonomi masyarakat Desa Mojoparon, kesempatan kerja meningkat. (2) Peranan langsung PIER yaitu bantuan infrastruktur desa seperti bantuan penerangan, rehab gorong-gorong dan jalan desa, sedangkan fasilitas berupa fasilitas transportasi yang dinamakan APAP. Sedangkan program atau kebijakan yang diberikan PIER yaitu program Bina Lingkungan (BK) dan Program Kemitraan (PK).

Dampak PIER bagi kehidupan sosial ekonomi masyarakat Desa Mojoparon yaitu adanya perubahan sistem ekonomi yang terjadi. Perubahan tersebut nampak dari perubahan pekerjaan utama petani menjadi pekerja industri. Hal tersebut membuat masyarakat Desa Mojoparon menjadi lebih sejahtera. Dampak sosial yang timbul ialah berubahnya pola pikir dan sifat masyarakat, seperti individulis, materialistis dan munculnya masalah kecemburuan sosial. Manfaat penelitian ini bagi pendidikan dapat dijadikan tambahan wawasan dan kajikan bagi pendidikan IPS yang diharapkan peserta didik yang mampu memahami materi peranan industri bagi masyarakat sekitar akan dapat menumbuhkan sikap peka sosial, mental positif dan terampil.

\section{Daftar Rujukan}

Anonim. (2014). Sier-Pier the Wise Choice for Smart Solution. Retrieved from http://www.sier-pier.com/

Statistik, B. P. (2015). Statistik Tebu Indonesia. Sub Direktorat Statistik tanaman Perkebunan. Jakarta. 116-127.

Darojah, U., Wasino, W., \& Prasetyo, P. E. (2012). Perubahan struktur sosial ekonomi dari ekonomi pertanian ke ekonomi industri pada masyarakat Desa Kubangwungu Kecamatan Ketanggungan Kabupaten Brebes Tahun 1969-2010. Journal of educational social studies, 1(2). 78-83 
Jurnal Integrasi dan Harmoni Inovatif Ilmu-Ilmu Sosial (JIHI3S), 1(3), 2021, 285-292

Departemen Pendidikan Nasional. (2008). Kamus Besar Bahasa Indonesia (Edisi Keempat). Jakarta: PT. Gramedia Pusaka Utama.

Djunaedi, M. H. (2009). Analisis Proyeksi Kesempatan Kerja Dan Produktivitas Tenaga Kerja Di Kabupaten Lombok Barat 2010-2025. Jurnal Ekonomi Pembangunan, 7(2), 113-124.

Ernita, D., Amar, S., \& Syofyan, E. (2013). Analisis pertumbuhan ekonomi, investasi, dan konsumsi di Indonesia. Jurnal Kajian Ekonomi, 1(2), 176-193.

Fahrudin, A. (2012). Pengantar Kesejahteraan Sosial. Bandung: PT. Refika Aditama.

Kartasapoetra, G. (1985). Sosiologi industri. Jakarta: Bina Aksara.

Kartasapoetra, G. Kartasapoetra, A.G. Kartasapoetra, R.G. (1987). Pembentukan Perusahaan Industri. Jakarta: PT. Bina Aksara.

Kementerian Pendidikan dan Kebudayaan Republik Indonesia. (2013). Lampiran Peraturan Menteri Pendidikan dan Kebudayaan Nomor 68 Tahun 2013 Tentang Kerangka Dasar dan Struktur Kurikulum Sekolah Menengah Pertama/Madrasah Tsanawiyah. Jakarta: Kementerian Pendidikan dan Kebudayaan Republik Indonesia.

Kwanda, T. (2004). Pengembangan kawasan industri di Indonesia. DIMENSI (Journal of Architecture and Built Environment), 28(1), 54-61.

Ritzer, G., \& Goodman, D. J. (2007). Teori Sosiologi Modern, Edisi Ke-6. Diterjemahkan oleh Alimandan. Jakarta: Kencana.

Salim, A., \& Kahono, G. B. (2013). Fenomena kemiskinan pada masyarakat petani sawah (studi kasus pada petani sawah di Desa Karang Anyar Kec. Jati Agung Kab. Lampung Selatan). SOCIOLOGIE, 1(1), 53-59.

Salim, I. (2010). Aliran Filsafat Eksistensialis. Jurnal Pendidikan Sosiologi dan Humaniora, 183-190.

Siswanta, L. (2011). Analisis Faktor Faktor yang Mempengaruhi Pendapatan Perajin Genteng (Studi Kasus Pada Industri Kerajinan Genteng Di Ceper Klaten). Jurnal Akmenika UPY, 7(2014)74-88.

Soepono, S. S., \& Sitanggang, H. (1995). Corak dan pola kehidupan sosial ekonomi pedesaan: studi tentang kewiraswastaan pada masyarakat di Plered. Proyek Pengkajian dan Pembinaan Nilai-Nilai Budaya, Direktorat Sejarah dan Nilai Tradisional, Direktorat Jenderal Kebudayaan, Departemen Pendidikan dan Kebudayaan.

Soerjono, S. (2012). Sosioloi Suatu Pengantar. Jakarta: PT Raja Grafindo Persada.

Trianto. (2007). Model Pembelajaran Terpadu dalam Teori dan Praktek. Jakarta: Prestasi Pustaka.

Widiyanarti, T. (2005). Corporate Social Responsibility: Model Community Development Oleh Korporat. Jurnal Antropologi Sosial Budaya ETNOVISI, 1(2), 78-79. 